\title{
Article \\ Insights into the Restoration of Tributyltin Contaminated Environments Using Marine Bacteria from Portuguese Fishing Ports
}

\author{
Hugo R. Monteiro ${ }^{1, *(\mathbb{D})}$, Ariana B. Moutinho ${ }^{1}$, Maria J. Campos ${ }^{1} \mathbb{D}$, Ana C. Esteves ${ }^{2}$ (D) and Marco F. L. Lemos ${ }^{1, * \mathbb{D}}$ \\ 1 MARE-Marine and Environmental Sciences Centre, ESTM, Polytechnic of Leiria, 2520-641 Peniche, Portugal; \\ ariana.moutinho@ipleiria.pt (A.B.M.); mcampos@ipleiria.pt (M.J.C.) \\ 2 CESAM-Centre for Environmental and Marine Studies, Department of Biology, University of Aveiro, \\ 3810-193 Aveiro, Portugal; acesteves@ua.pt \\ * Correspondence: hugo.monteiro@ipleiria.pt (H.R.M.); marco.lemos@ipleiria.pt (M.F.L.L.); \\ Tel.: +351-262-783-607 (H.R.M. \& M.F.L.L.); Fax: +351-262-783-088 (H.R.M. \& M.F.L.L.)
}

check for

updates

Citation: Monteiro, H.R.; Moutinho, A.B.; Campos, M.J.; Esteves, A.C.; Lemos, M.F.L. Insights into the Restoration of Tributyltin Contaminated Environments Using Marine Bacteria from Portuguese Fishing Ports. Appl. Sci. 2021, 11, 6411. https://doi.org/10.3390/ app11146411

Academic Editor: Elida Nora Ferri

Received: 17 June 2021

Accepted: 9 July 2021

Published: 12 July 2021

Publisher's Note: MDPI stays neutral with regard to jurisdictional claims in published maps and institutional affiliations.

Copyright: (c) 2021 by the authors. Licensee MDPI, Basel, Switzerland. This article is an open access article distributed under the terms and conditions of the Creative Commons Attribution (CC BY) license (https:// creativecommons.org/licenses/by/ $4.0 /)$.

\begin{abstract}
Tributyltin (TBT) is an organotin chemical mainly used as biocide in marine antifouling paints. Despite the restrictions and prohibitions on its use, TBT is still an environmental problem due to its extensive application and subsequent release into the environment, being regarded as one of the most toxic chemicals released into the marine ecosystems. Microorganisms inhabiting impacted sites are crucial for their restoration since they have developed mechanisms to tolerate and break down pollutants. Nonetheless, transformation products resulting from the degradation process may still be toxic or, sometimes, even more toxic than the parent compound. The determination of the parent and degradation products by analytical methods, although necessary, may not be ecologically relevant since no information is provided regarding their ecotoxicity. In this study, marine bacteria collected from seven Portuguese fishing ports were isolated and grown in the presence of TBT. Bacteria that exhibited higher growth were used to bioremediate TBT-contaminated waters. The potential of these bacteria as bioremediation agents was evaluated through ecotoxicological assays using the sea snail Gibbula umbilicalis as model organism. Data suggested that some TBT-tolerant bacteria, such as Pseudomonas putida, can reduce the toxicity of TBT contaminated environments. This work contributes to the knowledge of TBT-degrading bacteria.
\end{abstract}

Keywords: bioremediation; ecotoxicology; Gibbula umbilicalis; marine bacteria; tributyltin; TBT-tolerance

\section{Introduction}

Tributyltin (TBT) is an organotin chemical that acts as a biocide in antifouling systems. Since the 1960s up until its ban in the late 2000s, TBT was widely employed in marine paints, successfully preventing the attachment of crustaceans, mollusks, algae and slime on boat hulls and various immersed structures and equipment [1-3]. The massive use of TBT led to the contamination of the environment, mainly marine and freshwater ecosystems, being ports, harbors, and marinas the most affected and historically contaminated sites due to high boat traffic [4-7]. Research undertaken since the 1970s unveiled the haunting toxicity of TBT to non-target organisms [8-12].

As a result, the European Union (EU) restricted its use on ships smaller than $25 \mathrm{~m}$ with the directive 89/677/CEE [13] and in 2003 with the regulation 782/2003/EC, banned the use of paints containing organotins in EU ships [14]. In 2008, the United Nations' International Maritime Organization called for a global prohibition of organotin-based paints on ship hulls $[6,8,15]$. Despite restrictions, TBT is still present on a global scale, in water and sediments at higher levels than those reported to cause detrimental effects on living organisms. This evidence suggests a recent illegal use of TBT-based antifouling paints [16-18]. Once released from an antifouling coating, TBT can be adsorbed to sus- 
pended particles in the water, biota, and sediment, and persist in the environment for long periods because of its low degradation rates $[16,18,19]$.

Tributyltin is a known endocrine disruptor compound that causes several adverse effects in different organisms, from invertebrates to mammals [20-22]. A well-documented adverse effect is imposex: the development of male sexual characteristics in female gastropods [16]. Imposex has been reported in sea snails at concentrations as low as $1 \mathrm{ng} \mathrm{L}^{-1}$ [23], significantly impacting sea snails' population dynamics. Despite the decreasing levels of imposex in the Portuguese Coast since its ban in 2008, a complete recovery of imposex on marine gastropods has not yet been achieved [16]. For this reason, TBT is still recognized as an important environmental problem on a global scale and often considered one of the most toxic substances released into the marine environment [19].

Microorganisms from historically impacted sites can develop a tolerance to pollutants and, in some cases, degrade them, which can be a crucial factor in the recovery of contaminated environments [24]. Despite TBT toxicity, tolerance in some bacteria has been reported [25]. Under favorable conditions, TBT may be biodegraded via sequential dealkylation processes to form dibutyltin (DBT), monobutyltin (MBT) and eventually inorganic tin, decreasing its toxicity in the process $[8,26]$. Another proposed mechanism of bacterial TBT degradation is the use of TBT as a carbon source [25-27]. Despite this increasing number of studies, the use of naturally occurring microorganisms for remediation of TBT is still far from a full-scale application as information on the actual mechanisms involved in the degradation process is still scarce $[25,28]$.

Moreover, the breakdown of TBT must be carefully followed as these by-products may still exert some toxicity to marine organisms. Hence, besides plain analytical reasoning, ecotoxicological testing on bioremediated media is needed to determine the actual biological damage of these degradation products.

Gibbula umbilicalis is a sea snail with a very wide distribution across the rocky shores of the European Atlantic coast. This species is very abundant and easy to collect and maintain in the laboratory, features that make it a good model in ecotoxicology $[29,30]$ and suitable model for monitoring TBT pollution.

In the present study, TBT-tolerant bacteria collected from Portuguese maritime ports were isolated and characterized, with the main goal of determining the potential of these isolates to bioremediate TBT into less toxic compounds. Additionally, to evaluate bioremediation efficiency, G. umbilicalis sea snails were exposed to potential bioremediated media, using survival as an endpoint.

\section{Materials and Methods}

\subsection{Study Area and Sample Collection}

Seawater samples were collected from seven Portuguese ports with high maritime traffic: Póvoa de Varzim (41.376120, -8.766945); Leixões (41.195238, -8.684177); Aveiro (40.645899, -8.727098); Figueira da Foz (40.146848, -8.849176); Peniche (39.355422, -9.375479); Setúbal (38.521228, -8.887277); and Sines (37.950219, -8.864599). All samples were collected during low tide, $50 \mathrm{~cm}$ above sediment level. Physicochemical parameters (temperature, $\mathrm{pH}$, salinity, conductivity, and dissolved oxygen) were measured using a multiparameter water meter (Hanna HI 9828; Hanna Instruments, Villafranca Padovana, Italy). At each sampling location, water samples were collected for bacteria isolation and for chemical analyses (butyltins and metallic elements). Samples were processed within $8 \mathrm{~h}$ of collection.

\subsection{Chemical Analyses}

Chemical analyses of butyltins (tributyltin, dibutyltin and monobutyltin) were made at the Instituto Superior Técnico (Lisbon, Portugal). Samples were derivatized with tetraethylborate and analyzed by GC-MS (RTX-5MS column $(30 \mathrm{~mm} \times 0.25 \mathrm{~mm} \times 0.25 \mu \mathrm{m})$ ) using tributyltin chloride, dibutyltin chloride and monobutyltin chloride as standards. Metals analyses were conducted at the University of Aveiro (Aveiro, Portugal) for the following metallic elements: silver $(\mathrm{Ag})$, cadmium $(\mathrm{Cd})$, cobalt $(\mathrm{Co})$, chromium $(\mathrm{Cr})$, copper $(\mathrm{Cu})$, 
iron $(\mathrm{Fe})$, manganese $(\mathrm{Mn})$, nickel $(\mathrm{Ni})$, lead $(\mathrm{Pb})$, strontium $(\mathrm{Sr})$, zinc $(\mathrm{Zn})$, tin $(\mathrm{Sn})$ and mercury (Hg). Samples were acidified and analyzed by ICP-MS using an internal standard (ISO 17294), except for mercury which was determined using gold as a stabilizing agent, as described by Allibone et al. [31]. The limits of detection were as follows: $50 \mu \mathrm{g} \mathrm{L}{ }^{-1}$ for Fe, $20 \mu \mathrm{g} \mathrm{L}^{-1}$ for $\mathrm{Zn}, 10 \mu \mathrm{g} \mathrm{L}{ }^{-1}$ for $\mathrm{Ni}$ and $\mathrm{Ag}, 5 \mu \mathrm{g} \mathrm{L}^{-1}$ for $\mathrm{Cr}$, Cu and Sn, $2 \mu \mathrm{g} \mathrm{L}{ }^{-1}$ for Mn, $\mathrm{Co}$ and $\mathrm{Pb}, 1 \mu \mathrm{g} \mathrm{L}{ }^{-1}$ for $\mathrm{Cd}$, and $0.5 \mu \mathrm{g} \mathrm{L}^{-1}$ for $\mathrm{Hg}$.

\subsection{Bacteria Isolation and Selection}

\subsubsection{Bacteria Isolation}

Tributyltin (tributyltin chloride, 96\%; Sigma-Aldrich, Madrid, Spain) 1.23 M stock solution was prepared in ethanol. Bacteria were grown in Tryptic Soy Agar (TSA; Sharlau, Barcelona, Spain) with $1.5 \%(\mathrm{w} / \mathrm{v}) \mathrm{NaCl}$ and contaminated with $0.1,1$, and $3 \mathrm{mM}$ TBT, adjusting the total volume of ethanol in all media to $1 \%(\mathrm{v} / \mathrm{v})$. Control groups were prepared with no TBT and $1 \%$ ethanol.

Water samples were vacuum filtered through a $0.45 \mu \mathrm{m}$ pore cellulose membrane filter (Sartorius Stedim Biotech, Göttingen, Germany), placed on TSA/TBT media (three replicates per concentration for each sampling site) and incubated at $30^{\circ} \mathrm{C}$. After $48 \mathrm{~h}$, colony-forming units (CFU) were counted and $3 \mathrm{mM}$ TBT-tolerant bacteria from one plate per location were isolated and purified by streak plate method.

\subsubsection{REP-PCR Genomic Fingerprinting}

Genomic DNA extraction was made with $250 \mu \mathrm{L}$ of a fresh culture in Tryptic Soy Broth (TSB, Sharlau, Barcelona, Spain). Cells were centrifuged for $5 \mathrm{~min}$ at $15,680 \times g$ and resuspended in $50 \mu \mathrm{L}$ Tris-EDTA (TE) buffer. Cells were lysed with $5 \mu \mathrm{L}$ of Lysozyme $(10 \mathrm{mg} / \mathrm{mL})$ and incubated for $1 \mathrm{~h}$ at $37^{\circ} \mathrm{C}$, followed by a $10 \mathrm{~min}$ incubation at $65^{\circ} \mathrm{C}$ with $50 \mu \mathrm{L}$ of Lysis Solution (Genomic DNA purification kit, Fermentas, Baden-Württemberg, Germany). Next, $100 \mu \mathrm{L}$ of chloroform was added to the lysate and spun 5 min at $15,680 \times g$. The aqueous phase was collected and mixed with $100 \mu \mathrm{L}$ of isopropanol, followed by centrifugation at $15,680 \times g$ for $10 \mathrm{~min}$. The resulting pellet was washed with $100 \mu \mathrm{L}$ of $70 \%$ ethanol, centrifuged ( $5 \mathrm{~min}, 15,680 \times \mathrm{g}$ ), dried and finally resuspended in $50 \mu \mathrm{L}$ of TE buffer and stored at $-20^{\circ} \mathrm{C}$. Prior to PCR reaction, an agarose gel electrophoresis was performed to verify DNA quality and extraction efficiency.

The REP-PCR reaction was performed with the following primer sequences: REP1R (5' III ICG ICG ICA TCI GGC 3') and REP2I (5' ICG ICT TAT CIG GCC TAC 3') [32]. A reaction mixture was prepared as follows: $11.15 \mu \mathrm{L}$ of water, $5 \mu \mathrm{L}$ of $5 \mathrm{x}$ buffer, $3 \mu \mathrm{L}$ of $\mathrm{MgCl}_{2}(25 \mathrm{mM}), 1.5 \mu \mathrm{L}$ of dNTP solution ( $2 \mathrm{mM}$ of each dNTP), $1.25 \mu \mathrm{L}$ of DMSO, $1 \mu \mathrm{L}$ of each primer $(10 \mathrm{mM})$ and $0.1 \mu \mathrm{L}$ of Taq polymerase. One $\mu \mathrm{L}$ of DNA was used as a template. PCR amplification was performed using a MyCycler Thermal Cycler (BioRad, Hercules, CA, USA) with an initial denaturation step at $95^{\circ} \mathrm{C}$ for 5 min followed by 30 cycles of denaturation at $94{ }^{\circ} \mathrm{C}$ for $1 \mathrm{~min}$, annealing at $40^{\circ} \mathrm{C}$ for $1 \mathrm{~min}$ and extension at $65^{\circ} \mathrm{C}$ for $8 \mathrm{~min}$. The final extension was carried at $65^{\circ} \mathrm{C}$ for $16 \mathrm{~min}$. PCR products were evaluated by ethidium bromide-stained agarose gel electrophoresis and characterized by Dice/UPGMA clustering [33]. Image acquisition was carried using a GelDoc (Bio-Rad, Hercules, CA, USA) imaging system and banding patterns were analyzed with GelCompar II 3.0 (Applied Maths, Kortrijk, Belgium).

\subsubsection{Bacteria Selection}

Selected bacterial phylotypes were grown in TSB until reaching an optical density (O.D.) of 0.600 at $570 \mathrm{~nm}$. Afterwards, the isolates were grown in TSB with 0, 1, 3 and $6 \mathrm{mM}$ of TBT and incubated at $160 \mathrm{rpm}$ and $30^{\circ} \mathrm{C}$. Absorbance was measured in a microplate reader (Labsystems Multiskan EX, Helsinki, Finland) every 30 min until the stationary phase. The faster-growing bacteria in high concentrations of TBT were selected for bioremediation assay. 


\subsection{Bioremediation Assay}

Two isolates (S13 and F3) were selected (Supplementary data S1, Figure S2). The experimental setup consisted of glass vessels containing sterile seawater with $500 \mu \mathrm{g} \mathrm{L}{ }^{-1}$ of TBT. Each bacterial inoculum (0.1\% TSB with O.D. $=0.600)$ was added to the contaminated media. In parallel, vessels containing sterile seawater and each inoculum were prepared to evaluate possible toxic by-products of bacteria growth. In addition, a negative control consisting of $0.1 \%$ TSB in sterile seawater was carried out. Three replicates were made per treatment and kept away from light for $48 \mathrm{~h}$ at $20 \pm 1{ }^{\circ} \mathrm{C}$, with continuous aeration. For the ecotoxicological testing, contents were filtered by pore size $0.45 \mu \mathrm{m}$ cellulose membranes and stored in amber glass bottles at $4{ }^{\circ} \mathrm{C}$ until used $(<8 \mathrm{~h})$.

\subsection{Gibbula umbilicalis Acute Toxicity Tests}

\subsubsection{Preliminary TBT Ecotoxicity Testing}

The acute toxicity of TBT was determined using the marine gastropod G. umbilicalis (da Costa, 1778) as model organism. Sea snails were collected during low tide in Peniche (central Portuguese coast), acclimated in glass tanks with clean natural seawater (34 PSU) at $20 \pm 1{ }^{\circ} \mathrm{C}$ for two weeks with a $16 \mathrm{~h}: 8 \mathrm{~h}$ light:dark cycle. The snails were fed ad libitum with the seaweed Ulva lactuca (Linnaeus, 1753). Snails with similar shell size $(10 \pm 2 \mathrm{~mm})$ were selected and starved $24 \mathrm{~h}$ prior to the tests. Sea snails were exposed in $60 \mathrm{~mL}$ glass vessels filled with $0.01,0.05,0.2,0.5,1,2,5,10,25,50$, and $100 \mu \mathrm{g} \mathrm{L}^{-1}$ of TBT (nominal concentrations) and covered with tulle netting. Eight replicates consisting of one individual per vessel were used per concentration. After 48 and $96 \mathrm{~h}$, mortality was checked by mechanical stimulation of the operculum and the median lethal concentration $\left(\mathrm{LC}_{50}\right)$ determined.

\subsubsection{TBT Remediation Ecotoxicity Testing}

A similar setup was used to assess the ability of bacteria collected from marine ports to bioremediate TBT-contaminated waters. An acute test was performed exposing the snails to increasing dilutions of each treated media: $20,12.2,7.6,4.6,2.8,1.8,1,0.7$, and $0.4 \%$ of the initial media (500 $\mu \mathrm{g} \mathrm{L}^{-1}$ or $100 \%$ ). In parallel, the following control groups were added to the experiment: (1) a contaminated (untreated) media with TBT using the same dilution range; (2) sterile seawater with each bacterial inoculum and (3) sterile seawater with $0.1 \%$ TSB (negative control), aerated for $48 \mathrm{~h}$. Concentrations were chosen based on preliminary range-finding tests and literature search of environmentally relevant TBT concentrations. After 48,72 , and $96 \mathrm{~h}$ of exposure, mortality was recorded and the $\mathrm{LC}_{50}$ estimated.

\subsection{Bacterial Identification}

Selected isolates were identified using a MALDI-TOF MS at the Hospital San Pedro de Alcántara (Cáceres, Spain). A characteristic spectrum was generated, specific for each species and compared to a reference database. A similarity over 2.0 indicated an identification at the species level [34].

\subsection{Statistical Analysis}

One-way analysis of variance (ANOVA) was performed to analyze the number of colony-forming units amongst treatments, followed by Dunnett's post hoc test to determine significant differences between experimental treatments and controls. Data were checked for homoscedasticity and residual normality and when needed, data were log-transformed to correct for non-normality. Median lethal concentrations $\left(\mathrm{LC}_{50^{\prime}} \mathrm{s}\right)$ were determined using four-parameter logistic curves and compared using the extra sum-of-squares F test. All statistical analyses were performed using GraphPad Prism 9 (GraphPad Software Inc., San Diego, CA, USA) and the significance level ( $p$-value) was set at 0.05 . 


\section{Results}

\subsection{Chemical Analyses}

Physicochemical parameters and chemical analyses of metallic elements are presented in supplementary data (Supplementary data S1, Tables S1 and S2). The concentration of butyltins (TBT, DBT, and MBT) was $<50 \mathrm{ng} \mathrm{L}^{-1}$ and inorganic tin concentration was $<5 \mu \mathrm{g} \mathrm{L}^{-1}$ on all sampling locations. Leixões was the port with the highest level of metal contamination, with $\mathrm{Pb}, \mathrm{Mn}$, and $\mathrm{Zn}$ detected at 2.2, 17.7, and $36 \mu \mathrm{g} \mathrm{L}^{-1}$, respectively.

\subsection{Colony-Forming Units and Percentage of Tolerant Bacteria}

The concentration of CFUs decreased with increasing TBT concentration, as did the relative abundance (\%) of tolerant bacteria when compared to the control. At $0.1 \mathrm{mM}$ TBT (Figure 1), Póvoa de Varzim sample presented the highest percentage of tolerant bacteria ( $45.5 \pm 6.8 \%$ ) while Setúbal had the lowest $(2.6 \pm 0.7 \%)$. At $1 \mathrm{mM}$ and $3 \mathrm{mM} \mathrm{TBT}$, Peniche port water exhibited the highest percentage of tolerants $(8.2 \pm 0.5 \%$ and $7.7 \pm 1.8 \%$, respectively) as well as the highest absolute abundance of CFUs $\left(410 \pm 26 \mathrm{CFU} \mathrm{mL} \mathrm{m}^{-1}\right.$ and $383 \pm 91 \mathrm{CFU} \mathrm{mL}{ }^{-1}$, respectively). Aveiro $(0.3 \pm 0.1 \%)$ and Setúbal $(0.1 \pm 0.03 \%)$ exhibited the lowest percentage of tolerant bacteria to $1 \mathrm{mM}$ and $3 \mathrm{mM}$, respectively. Aveiro also presented the lowest abundance of cultivable isolates even in the absence of TBT, while Peniche presented the highest. Significant differences between TBT-contaminated media and control group were verified for all sampling sites. In total, 157 isolates tolerant to $3 \mathrm{mM}$ TBT were purified by streaking technique and used in subsequent assays.

\subsection{Bacterial Selection for Bioremediation}

Following a cluster analysis of REP-PCR fingerprints, a total of 111 isolates from 157 genetic profiles were regarded as different phylotypes (cut off set at 94\% similarity; Supplementary data S1, Figure S3). Similarity ranged from $37.5 \%$ to $100 \%$, with the sample from Figueira da Foz showing the highest variability and Peniche the lowest. To further select the most promising bioremediation candidates, bacteria were grown in high concentrations of TBT (from 1 to $6 \mathrm{mM}$ ).

Two strains were selected according to their growth in the presence of $6 \mathrm{mM}$ TBT (Supplementary data S1, Figure S2). Bacteria selected for bioremediation assays were S13 and F3. Strain S13 was identified as the gram-negative bacteria Pseudomonas putida and strain F3 was identified as the gram-negative Serratia marcescens.

\subsection{Acute Toxicity Tests}

The $48 \mathrm{~h}$ and $96 \mathrm{~h} \mathrm{LC}_{50^{\prime}} \mathrm{s}$ (95\% Confidence Interval) of TBT for G. umbilicalis were estimated as $61.96 \mu \mathrm{g} \mathrm{L}^{-1}$ (60.62-63.33) and $15.73 \mu \mathrm{g} \mathrm{L}{ }^{-1}$ (13.84-17.88), respectively (Supplementary data S1, Figure S1). Regarding the exposure to potentially bioremediated media, $\mathrm{LC}_{50}$ values are presented as a percentage of the initial TBT solution $\left(500 \mu \mathrm{g} \mathrm{L}^{-1}\right.$; Table 1). After $48 \mathrm{~h}$ of exposure, it was only possible to estimate the $\mathrm{LC}_{50}$ for the TBT-untreated media, as $17.02 \%$ (16.20-17.94) since no mortality was recorded in the remaining treatments. For the remediation treatments, the $\mathrm{LC}_{50}$ was estimated to be higher than $20 \%$ (the highest concentration tested). After $72 \mathrm{~h}$, the $\mathrm{LC}_{50}$ for the TBT-untreated media was estimated as $8.40 \%(8.19-8.62)$, with higher $\mathrm{LC}_{50}$ values estimated for the remediation treatments, suggesting a decrease in toxicity of treated media. For the treatment with bacteria S13, the $\mathrm{LC}_{50}$ was still estimated to be higher than $20 \%$. A similar outcome was observed after $96 \mathrm{~h}$ of exposure, with the lowest $\mathrm{LC}_{50}$ estimated for the TBT-untreated media (5.91\% (8.89-5.93)) and the highest for the treatment with bacteria S13 (Table 1). 

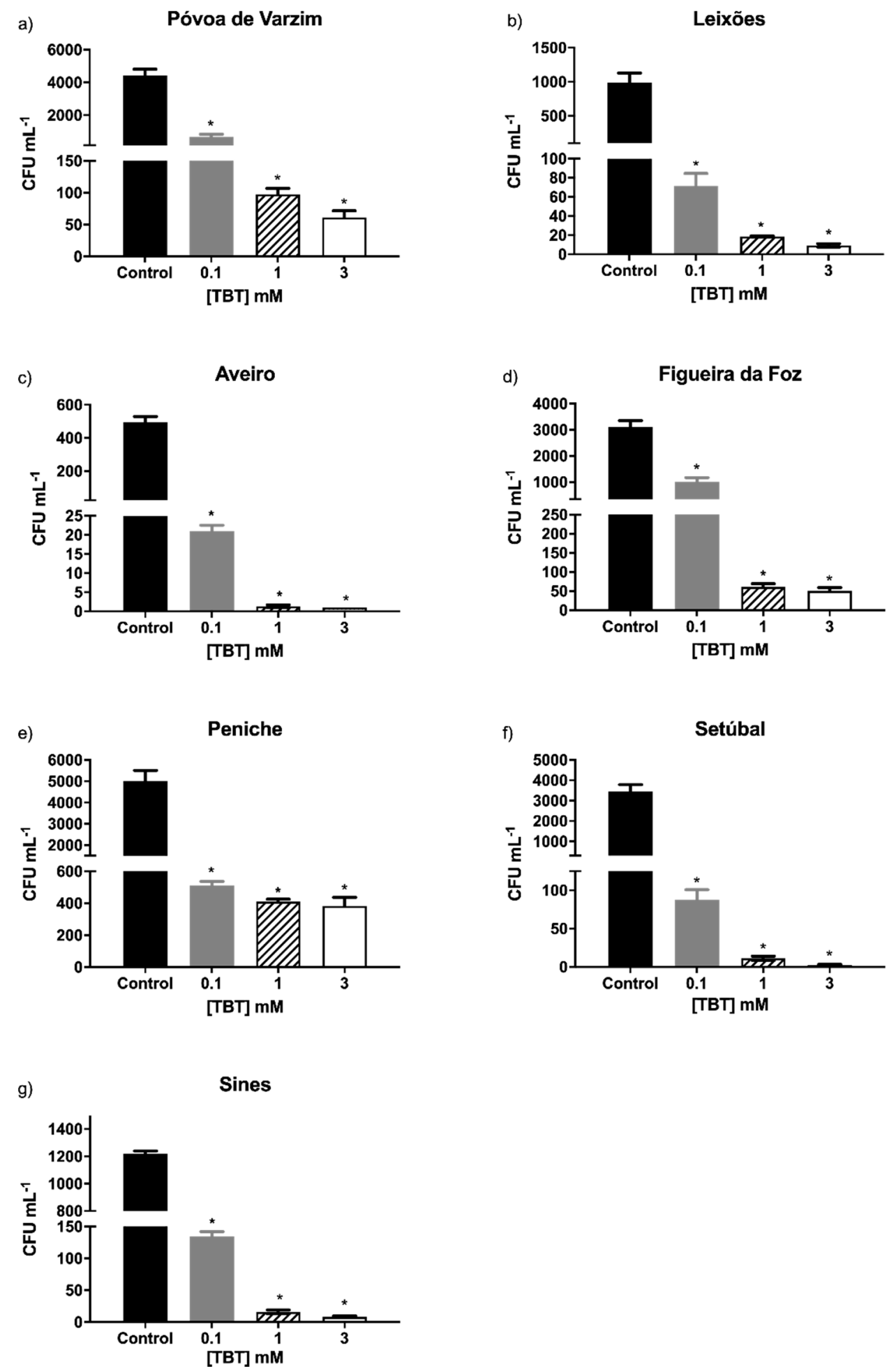

Figure 1. Relationship between concentration of tributyltin $(0,0.1,1$, and $3 \mathrm{mM})$ and CFUs for all sampling sites (a) Póvoa de Varzim; (b) Leixões; (c) Aveiro; (d) Figueira da Foz; (e) Peniche; (f) Setúbal; (g) Sines. Results presented as mean + SEM. Asterisk indicates significant differences between treatments and control, $p<0.05$. 
Table 1. Lethal concentration values estimated for Gibbula umbilicalis exposed to untreated and bioremediated media. Strain S13: Pseudomonas putida; Strain F3: Serratia marcescens. Asterisk $\left(^{*}\right)$ indicates significant differences in $\mathrm{LC}_{50}$ between bioremediated treatments and untreated media. n.d.-not determined.

\begin{tabular}{cccc}
\hline Exposure Period & Treatment & LC $_{\mathbf{5 0}} \mathbf{( \% )}$ & $\mathbf{9 5 \%}$ Confidence Interval \\
\hline \multirow{3}{*}{$48 \mathrm{~h}$} & TBT & 17.02 & $16.20-17.94$ \\
& S13 + TBT & $>20$ & n.d. \\
& F3 + TBT & $>20$ & n.d. \\
\hline \multirow{3}{*}{$72 \mathrm{~h}$} & TBT & 8.40 & $8.19-8.62$ \\
& S13 + TBT & $>20$ & n.d. \\
& F3 + TBT & $19.90^{*}$ & $13.89-45.32$ \\
\hline \multirow{2}{*}{$96 \mathrm{~h}$} & TBT & 5.91 & $5.89-5.93$ \\
& S13 + TBT & $19.97^{*}$ & $19.63-20.34$ \\
& F3 + TBT & $10.21^{*}$ & $8.04-13.45$ \\
\hline
\end{tabular}

As mentioned, glass vessels with seawater (without TBT) inoculated with selected bacteria were maintained in the same conditions as described for the other treatments. Sea snails were exposed to increasing dilutions of these media. At $20 \%$ of the initial solution, no mortality was observed during the $96 \mathrm{~h}$ exposure period.

\section{Discussion}

Naturally occurring marine bacteria from Portuguese ports were grown and isolated in high concentrations of TBT and their decontamination potential was evaluated. The results suggest that TBT is highly selective and can negatively affect bacterial growth. A decrease in the CFUs abundance with increasing TBT concentrations was observed for all sampled sites. At $0.1 \mathrm{mM}$, the bacterial growth was affected, with a decrease of CFUs over $50 \%$ compared to the control, suggesting this low concentration is highly toxic.

In Peniche, the percentage of tolerant bacteria was constant with increasing TBT concentrations. Peniche was also the location with the highest percentage of tolerant bacteria at $3 \mathrm{mM}$ (7.7\% compared to control). These results may be explained by the initial pool of bacteria, which was the highest from all sampling sites. Butyltin's levels in collected waters were below the limit of quantification $\left(<50 \mathrm{ng} \mathrm{L}^{-1}\right)$ in all sampling sites. Marinas and ports are hotspots of TBT contamination due to boat traffic and shipyard activities [35,36]. Thus, it is expected that these sampling sites would be contaminated with TBT and that smaller concentrations of this highly toxic chemical might be present, particularly in sediments, where it persists [8,37]. Previous studies reported levels of butyltins in Portuguese waters. In 1999/2000, samples collected along Portuguese rivers and coastal waters revealed butyltins levels ranging from 23 to $79 \mathrm{ng} \mathrm{L}^{-1}$ [35]. In 1999, on Tagus estuary, TBT levels ranged from 1.1 to $21.1 \mathrm{ng} \mathrm{L}^{-1}$ [38]. Although those studies date back to the pre-ban period, a more recent study revealed that in 2014 TBT was still present in Portuguese coastal waters, since quantifiable amounts were detected in dog-whelks (Gastropoda) tissue samples [16].

Additionally, some studies refer the occurrence of TBT-tolerant bacteria to be related to the occurrence of other contaminants such as metals, making them cross-resistant to TBT [39]. Seaports are traditionally contaminated sites, making these heavily impacted sites more selective for bacteria that develop mechanisms to adapt to such conditions.

The REP-PCR method was used to characterize the 157 isolates tolerant to $3 \mathrm{mM}$ of TBT. One hundred and eleven different patterns were identified. Peniche port samples had the lowest level of diversity, with just 5 distinctive patterns identified using REP-PCR, sharing a similarity of more than $79 \%$, suggesting that the isolates from this location were genetically close to each other. This low diversity and higher initial pool of microorganisms (5000 $\pm 513 \mathrm{CFU} \mathrm{mL}{ }^{-1}$ ), may explain the high percentage of tolerant CFUs observed for this location. 
To select the most suitable strains for bioremediation assays, bacteria were exposed to $6 \mathrm{mM}$ TBT and two different strains were selected based on their growth in this condition. Although TBT inhibits the growth of these isolates, there were no apparent differences in growth between $1 \mathrm{mM}, 3 \mathrm{mM}$, and $6 \mathrm{mM}$. Cruz et al. [40] reported that gradually transferring bacteria to higher TBT concentrations increases their tolerance, suggesting a "memory response" mechanism, which could justify why some bacteria grew in such high concentrations since they were cultured and maintained in TBT-contaminated media.

Despite the importance of determining the levels of a toxicant and its by-products in the ecosystems, this does not provide information on the contaminant's toxicity and its degradation products. Such data can be obtained through ecotoxicological assays. In the present study, ecotoxicological testing with G. umbilicalis proved to be a solid approach to determine toxic effects of TBT. Still, the use of sub-lethal, and thus more sensitive endpoints [41] should also be considered in future studies to better estimate the harmful impacts of low levels of butyltins on gastropods. Pseudomonas putida (S13) showed the highest biodegradation potential of TBT-contaminated waters, as evidenced by the observed decrease in toxicity mediated by this bacterium. Pseudomonas putida was reported as a TBT-degrading bacteria that uses TBT as a carbon source [27]. The cultivation of P. putida in TBT-contaminated media suggests that the breaking down of TBT by this bacterium generates degradation products with a lower toxicity than the parent compound. The ecotoxicological approach used in this study, allows to show the relevant effect on important species. Nonetheless, follow up studies should be complemented with chemical analyses. An increase in $\mathrm{LC}_{50}$ was also observed for the treatment with Serratia marcescens (F3), suggesting that remediation of the media had occurred, as the medium became less toxic. Serratia marcescens has been regarded as a potential organotin-resistant bacteria [26] and here its tolerance is confirmed. To our knowledge, this is the first study concerning the potential of $S$. marcescens to bioremediate TBT-contaminated waters. Nonetheless, despite the decrease in toxicity of the treated media with this bacterium after $96 \mathrm{~h}$ of exposure, the media was still toxic to G. umbilicalis. This hints the possibility that some TBT may be still present in the media and a longer remediation period $(>48 \mathrm{~h}$ ) may be needed for a more effective TBT degradation. Additionally, toxic by-products may be generated, which should be monitored in future studies, considering that toxic degradation products may hamper the in situ application of TBT-degrading bacteria.

As demonstrated in this study, naturally present bacteria from Portuguese ports can tolerate TBT at high levels and eventually transform it into less toxic compounds, contributing towards ecosystem restoration. The results derived from the ecotoxicological testing demonstrated that P. putida and S. marcescens have the potential to step up TBT removal from contaminated marine environments and thus representing candidate remediation agents for application in bioremediation approaches. Since heavy metal and antibiotic resistance is frequent in TBT-resistant bacteria, exploring TBT-tolerant bacteria applications might be vital for the restoration of polluted environments in general. Knowledge of their genetics and physiology is key for their future application as natural decontamination facilitators.

Overall, the present study contributed to the growing knowledge of TBT-degrading bacteria. The decrease in toxicity observed strongly suggest that $P$. putida can transform TBT into less toxic products and that ecotoxicological testing can be a valuable tool in bioremediation studies as a complement of chemical analyses. Future research should focus on determining mechanisms underlying TBT resistance and biodegradation. Despite the decreasing trend observed over the past decades, TBT levels in water and biota are still matters of concern [42]. Existing prohibitions have not translated into a complete elimination of TBT and its by-products from the environment, particularly considering the persistent nature of these chemicals, and therefore there is still a paramount need to develop tools to transform and safely remove this chemical from the environment.

Supplementary Materials: The following are available online at https:/ / www.mdpi.com/article/10 .3390/app11146411/s1, Table S1: Physicochemical properties of near-sediment waters from sampling 
sites at Portuguese ports, Table S2: Metal quantification in near-sediment waters from sampling sites at Portuguese ports, Figure S1: Dose-response curves of Gibbula umbilicalis exposed to TBT for 48 and 96 h, Figure S2: Growth curves of bacteria in the presence of TBT (1, 3 and $6 \mathrm{mM})$, Figure S3: Dendrogram showing genetic similarity of isolated bacteria determined by analysis of REP-PCR fingerprint patterns using Dice similarity coefficient and UPGMA cluster methods.

Author Contributions: Conceptualization, H.R.M., A.C.E. and M.F.L.L.; Investigation, H.R.M. and M.J.C.; Resources, A.C.E. and M.F.L.L.; Supervision, A.C.E. and M.F.L.L.; Writing-original draft, H.R.M. and A.B.M.; Writing-review and editing, H.R.M., A.B.M., A.C.E. and M.F.L.L. All authors have read and agreed to the published version of the manuscript.

Funding: This study had the support of Fundação para a Ciência e a Tecnologia (FCT) through the Strategic Project UID/MAR/04292/2020 granted to MARE and UIDP/50017/2020+UIDB/50017/2020 granted to CESAM, through national funds and the co-funding by the FEDER, within the PT 2020 Partnership Agreement and Compete 2020.

Conflicts of Interest: The authors declare no conflict of interest.

\section{References}

1. Turner, A. Marine pollution from antifouling paint particles. Mar. Pollut. Bull. 2010, 60, 159-171. [CrossRef]

2. Omae, I. Organotin antifouling paints and their alternatives. Appl. Organomet. Chem. 2003, 17, 81-105. [CrossRef]

3. Li, Z.H.; Li, P. Effects of the tributyltin on the blood parameters, immune responses and thyroid hormone system in zebrafish. Environ. Pollut. 2021, 268, 115707. [CrossRef] [PubMed]

4. Bandara, K.R.V.; Chinthaka, S.D.M.; Yasawardene, S.G.; Manage, P.M. Modified, optimized method of determination of Tributyltin (TBT) contamination in coastal water, sediment and biota in Sri Lanka. Mar. Pollut. Bull. 2021, 166, 112202. [CrossRef] [PubMed]

5. Castro, Í.B.; Iannacone, J.; Santos, S.; Fillmann, G. TBT is still a matter of concern in Peru. Chemosphere 2018, 205, 253-259. [CrossRef] [PubMed]

6. International Maritime Organization. Focus on IMO Anti-Fouling Systems. London. 2002, pp. 1-31. Available online: https://www.imo.org/en/OurWork/Environment/Pages/Anti-fouling.aspx (accessed on 1 June 2021).

7. Undap, S.L.; Nirmala, K.; Miki, S.; Inoue, S.; Qiu, X.; Honda, M.; Shimasaki, Y.; Oshima, Y. High tributyltin contamination in sediments from ports in Indonesia and Northern Kyushu, Japan. J. Fac. Agric. Kyushu Univ. 2013, 58, 131-135. [CrossRef]

8. Antizar-Ladislao, B. Environmental levels, toxicity and human exposure to tributyltin (TBT)-contaminated marine environment. A review. Environ. Int. 2008, 34, 292-308. [CrossRef]

9. Choi, M.; An, Y.R.; Park, K.J.; Lee, I.S.; Hwang, D.W.; Kim, J.; Moon, H.B. Accumulation of butyltin compounds in finless porpoises (Neophocaena asiaeorientalis) from Korean coast: Tracking the effectiveness of TBT regulation over time. Mar. Pollut. Bull. 2013, 66, 78-83. [CrossRef] [PubMed]

10. De Castro, Í.B.; Perina, F.C.; Fillmann, G. Organotin contamination in South American coastal areas. Environ. Monit. Assess. 2012, 184, 1781-1799. [CrossRef]

11. Kannan, K.; Guruge, K.S.; Thomas, N.J.; Tanabe, S.; Giesy, J.P. Butyltin residues in southern sea otters (Enhydra lutris nereis) found dead along California coastal waters. Environ. Sci. Technol. 1998, 32, 1169-1175. [CrossRef]

12. Ünlü, S. Marine pollution from ships in the Turkish straits system. In The Sea of Marmara: Marine Biodiversity, Fisheries, Conservation and Governance; Özsoy, E., Çağatay, M.N., Balkıs, N., Balkıs, N., Öztürk, B., Eds.; Turkish Marine Research Foundation (TUDAV): Istanbul, Turkey, 2016; pp. 755-767. ISBN 9789758825349.

13. European Union. Council Directive of 21 December 1989 amending for for the eighth time Directive 76/769/EEC on the approximation of the laws, regulations and administrative provisions of the Member States relating to restrictions on the marketing and use of certain dange. Off. J. Eur. Communities 1989, L398, 19-23. Available online: http:// data.europa.eu/eli/dir/1989/677/oj (accessed on 1 June 2021).

14. European Union. Regulation (EC) No 782/2003 of the European Parliament and of the Council of 14 April 2003 on the prohibition of organotin compounds on ships. Off. J. Eur. Union 2003, 1-11. Available online: http://data.europa.eu/eli/reg/2003/782/oj (accessed on 1 June 2021).

15. Wang, X.; Fang, C.; Hong, H.; Wang, W.X. Gender differences in TBT accumulation and transformation in Thais clavigera after aqueous and dietary exposure. Aquat. Toxicol. 2010, 99, 413-422. [CrossRef]

16. Laranjeiro, F.; Sánchez-Marín, P.; Oliveira, I.B.; Galante-Oliveira, S.; Barroso, C. Fifteen years of imposex and tributyltin pollution monitoring along the Portuguese coast. Environ. Pollut. 2018, 232, 411-421. [CrossRef] [PubMed]

17. Abreu, F.E.L.; Lima da Silva, J.N.; Castro, Í.B.; Fillmann, G. Are antifouling residues a matter of concern in the largest South American port? J. Hazard. Mater. 2020, 398, 122937. [CrossRef] [PubMed]

18. Turk, M.; Ivanić, M.; Dautović, J.; Bačić, N.; Mikac, N. Simultaneous analysis of butyltins and total tin in sediments as a tool for the assessment of tributyltin behaviour, long-term persistence and historical contamination in the coastal environment. Chemosphere 2020, 258, 127307. [CrossRef] 
19. Okoro, H.K.; Fatoki, O.S.; Adekola, F.A.; Ximba, B.J.; Snyman, R.G. Organotin Compounds. Encycl. Toxicol. Third Ed. 2014, 3, 720-725. [CrossRef]

20. Guo, S.; Qian, L.; Shi, H.; Barry, T.; Cao, Q.; Liu, J. Effects of tributyltin (TBT) on Xenopus tropicalis embryos at environmentally relevant concentrations. Chemosphere 2010, 79, 529-533. [CrossRef]

21. Zou, E. Aquatic invertebrate endocrine disruption. In Encyclopedia of Animal Behavior, 2nd ed.; Choe, J.C., Ed.; Academic Press: Oxford, UK, 2019; pp. 470-482. ISBN 9780128132524.

22. Blaber, S.J.M. The occurrence of a penis-like outgrowth behind the right tentacle in spent females of Nucella lapillus (L.). J. Molluscan Stud. 1970, 39, 231-233. [CrossRef]

23. Gooding, M.P.; Wilson, V.S.; Folmar, L.C.; Marcovich, D.T.; LeBlanc, G.A. The biocide tributylin reduces the accumulation of testosterone as fatty acid esters in the mud snail (Ilyanassa obsoleta). Environ. Health Perspect. 2003, 111, 426-430. [CrossRef]

24. Kawai, S.; Kurokawa, Y.; Harino, H.; Fukushima, M. Degradation of tributyltin by a bacterial strain isolated from polluted river water. Environ. Pollut. 1998, 102, 259-263. [CrossRef]

25. Cruz, A.; Anselmo, A.M.; Suzuki, S.; Mendo, S. Tributyltin (TBT): A review on microbial resistance and degradation. Crit. Rev. Environ. Sci. Technol. 2015, 45, 970-1006. [CrossRef]

26. Dubey, S.K.; Roy, U. Biodegradation of tributyltins (organotins) by marine bacteria. Appl. Organomet. Chem. 2003, 17, 3-8. [CrossRef]

27. Sampath, R.; Venkatakrishnan, H.; Ravichandran, V.; Chaudhury, R.R. Biochemistry of TBT-degrading marine pseudomonads isolated from Indian coastal waters. Water. Air. Soil Pollut. 2012, 223, 99-106. [CrossRef]

28. Yáñez, J.; Riffo, P.; Santander, P.; Mansilla, H.D.; Mondaca, M.A.; Campos, V.; Amarasiriwardena, D. Biodegradation of tributyltin (TBT) by extremophile bacteria from atacama desert and speciation of tin by-products. Bull. Environ. Contam. Toxicol. 2015, 95, 126-130. [CrossRef] [PubMed]

29. Cabecinhas, A.S.; Novais, S.C.; Santos, S.C.; Rodrigues, A.C.M.; Pestana, J.L.T.; Soares, A.M.V.M.; Lemos, M.F.L. Sensitivity of the sea snail Gibbula umbilicalis to mercury exposure-Linking endpoints from different biological organization levels. Chemosphere 2015, 119, 490-497. [CrossRef]

30. Giménez, V.; Nunes, B. Effects of commonly used therapeutic drugs, paracetamol, and acetylsalicylic acid, on key physiological traits of the sea snail Gibbula umbilicalis. Environ. Sci. Pollut. Res. 2019, 26, 21858-21870. [CrossRef]

31. Allibone, J.; Fatemian, E.; Walker, P.J. Determination of mercury in potable water by ICP-MS using gold as a stabilising agent. J. Anal. At. Spectrom. 1999, 14, 235-239. [CrossRef]

32. Adiguzel, A.; Ozkan, H.; Baris, O.; Inan, K.; Gulluce, M.; Sahin, F. Identification and characterization of thermophilic bacteria isolated from hot springs in Turkey. J. Microbiol. Methods 2009, 79, 321-328. [CrossRef]

33. Tacão, M.; Alves, A.; Saavedra, M.J.; Correia, A. BOX-PCR is an adequate tool for typing Aeromonas spp. Antonie van Leeuwenhoek. Int. J. Gen. Mol. Microbiol. 2005, 88, 173-179. [CrossRef]

34. Wieser, A.; Schneider, L.; Jung, J.; Schubert, S. MALDI-TOF MS in microbiological diagnostics—identification of microorganisms and beyond (mini review). Appl. Microbiol. Biotechnol. 2012, 93, 965-974. [CrossRef]

35. Díez, S.; Lacorte, S.; Viana, P.; Barceló, D.; Bayona, J.M. Survey of organotin compounds in rivers and coastal environments in Portugal 1999-2000. Environ. Pollut. 2005, 136, 525-536. [CrossRef]

36. Dafforn, K.A.; Lewis, J.A.; Johnston, E.L. Antifouling strategies: History and regulation, ecological impacts and mitigation. Mar Pollut. Bull. 2011, 62, 453-465. [CrossRef] [PubMed]

37. Xiao, X.; Sheng, G.D.; Qiu, Y. Improved understanding of tributyltin sorption on natural and biochar-amended sediments. Environ. Toxicol. Chem. 2011, 30, 2682-2687. [CrossRef] [PubMed]

38. De Bettencourt, A.M.M.; Andreae, M.O.; Cais, Y.; Gomes, M.L.; Schebek, L.; Vilas Boas, L.F.; Rapsomanikis, S. Organotin in the Tagus estuary. Aquat. Ecol. 1999, 33, 271-280. [CrossRef]

39. Suehiro, F.; Mochizuki, H.; Nakamura, S.; Iwata, H.; Kobayashi, T.; Tanabe, S.; Fujimori, Y.; Nishimura, F.; Tuyen, B.C.; Tana, T.S.; et al. Occurrence of tributyltin (TBT)-resistant bacteria is not related to TBT pollution in Mekong River and coastal sediment: With a hypothesis of selective pressure from suspended solid. Chemosphere 2007, 68, 1459-1464. [CrossRef]

40. Cruz, A.; Caetano, T.; Suzuki, S.; Mendo, S. Aeromonas veronii, a tributyltin (TBT)-degrading bacterium isolated from an estuarine environment, Ria de Aveiro in Portugal. Mar. Environ. Res. 2007, 64, 639-650. [CrossRef]

41. Trenfield, M.A.; van Dam, J.W.; Harford, A.J.; Parry, D.; Streten, C.; Gibb, K.; van Dam, R.A. A chronic toxicity test for the tropical marine snail Nassarius dorsatus to assess the toxicity of copper, aluminium, gallium, and molybdenum. Environ. Toxicol Chem. 2016, 35, 1788-1795. [CrossRef]

42. Finnegan, C.; Ryan, D.; Enright, A.M.; Garcia-Cabellos, G. A review of strategies for the detection and remediation of organotin pollution. Crit. Rev. Environ. Sci. Technol. 2018, 48, 77-118. [CrossRef] 